\title{
Intertextual Madness in Hamlet: The Ghost's Fragmented Performativity
}

HILAIRE

KALLENDORF

Summary: This essay establishes King James I's Daemonologie and Reginald Scot's Discouerie of Witchcraft as intertexts for Hamlet. It demonstrates how the diabolical linguistic register borrowed from these intertexts both heightens the verisimilitude of Hamlet's madness and expands the performative potential of the Ghost. Performativity has often been discussed as a theme for this play, but usually only in relation to Hamlet himself. This essay avoids the reductionism of the "Ghost critics" and extends the performativity theme to the Ghost as well by offering him a diabolical mask to try on in addition to his many others.

Derformativity is "a specular technique that breaks up the action into $P$ acting-out, rehearsals and try-outs for a dramatic action that endlessly threatens (or promises) to revert to its theatrical origins, to collapse into theatricality." In a play such as Hamlet, where performativity is arguably one of the primary themes of the work, there are dramatic resources and resonances which would not be possible without the intertextual use of a diabolical linguistic register. The madness in Hamlet becomes more verisimilar because it is associated intertextually with demonic possession, and the Ghost appears more frightening because one of his intertextual masks is devilish. The purpose of this essay will be to demonstrate the intertextual use of the demonic register in the play and to explore the theme of performativity as one of its ramifications.

Let us pause for a moment at the outset to reflect on the nature of intertextuality and how it can illuminate our understanding of a play involved 
in this process. We will be talking about intertextual points of contact, especially in passages about the supernatural. In Performance, Culture, and Identity, Elizabeth Fine and Jean Speer use the very example which interests us - that of a ghost story. They discuss intertextuality as it relates to

the power of narrators to create meaning and project cultural values through different renditions of the same traditional ghost story.... [T] hese studies provide examples of the processes of "entextualization" and "recontextualization" in which a performance may be detached from one social situation (entextualized, decentered) and performed in another social situation (recontextualized, recentered). ${ }^{2}$

I think the terms used here fit the situation of this play perfectly. Certain key passages from two treatises which I have studied in relation to this play, The Discouerie of Witchcraft (1584) by Reginald Scot and Daemonologie (1597) by King James $\mathrm{I}^{3}{ }^{3}$ were entextualized from the genre of treatise and recontextualized in a drama. Roger Chartier explains how this recontextualization forms an appropriation of cultural goods, or the echo of a shared discourse:

Understood more sociologically than phenomenologically, the notion of appropriation makes it possible to appreciate the differences in cultural apportionment, in the creative invention that lies at the very heart of the reception process . . . . Here, the idea of appropriation is not taken in the sense defined by Foucault in Discourse on Language. Foucault considered the "social appropriation of discourses" as a procedure that controls them and an apparatus that limits their distribution - in other words, as one of the grand systems of the subjugation of discourse. [An alternative notion of appropriation, however,] focuses attention not on exclusions by confiscation but on the differences within shared usage .... [T] he diverse uses of the same cultural goods are rooted in the stable predispositions proper to each group. ${ }^{4}$

Thus these demonological ideas are "the same cultural goods" which are put to "diverse uses" by both treatise writers and playwrights.

But what do entextualization, appropriation, and recontextualization have to do specifically with Hamlet? The answer is simply that the entextualization of the relevant passages of these demonological treatises from their original positions in the cultural dialogue, along with their appropriation by Shakespeare and recontextualization in his play, alter our understanding of Hamlet's madness. They add to it another dimension, another voice - by offering a diabolical "mask" for the Ghost to try on.

These instances (and instantiations) of intertextuality become immensely relevant when we consider that the cultural and linguistic processes of entextualization, appropriation, and recontextualization inevitably 
result in the fragmentation of discourse. Hamlet is considered by many critics to be a play about madness. And what is madness but one potential fragmentation of discourse? Alison Findlay reminds us in her essay "Hamlet: A Document in Madness" that

[i]dentity and madness are verbally constructed .... [L]etters, words and languages are themselves mad. Like the symptoms of melancholy, they carry a plurality of meanings, an excess of interpretations ... eliminating the difference between language and the insanity it seems to subjugate .... [M]adness produces and is produced by a fragmentation of discourse. 5

Findlay of course follows Foucault, who, in Madness and Civilisation, addresses the phenomenon of discourse fragmentation in which " $[\mathrm{m}]$ eaning is no longer read in an immediate perception .... [The sign is] burdened with supplementary meanings, and forced to express them. And dreams, madness, the unreasonable can also slip into this excess of meaning." $6 \mathrm{He}$ could have been describing Hamlet.

The theme of performativity as employed in Hamlet has been emphasized by many critics:

Hamlet has made his exits and his entrances; he has indeed played many parts. Shakespeare, in fact, has had Hamlet play the roles of virtually all the stock characters of Elizabethan drama: the melancholy gentleman in sable suit; the ungartered and downgyved mad lover; the Fool who makes knavish speeches . . . the malcontent; the noble prince; and even ... the villain ... . Hamlet was just such a "natural actor" who strove to express his complex, manifold personality by acting out various parts corresponding to his shifting moods and alternating character facets. ${ }^{7}$

But these critics have limited the performative aspect of the play to discussions of Hamlet, not of the Ghost. By giving the Ghost another rôle to perform, the discourse fragments from demonology found within the play contribute to its rich texture of multiple layers and levels of interpretation. By showing that the discourse of the play is even more fragmented and allusive than we have previously recognized, I shall demonstrate how Shakespeare used the performativity of language itself to increase the plausibility of Hamlet's madness.

If I may borrow Roland Frye's caveat, "[o]ur task ... will thus not be to find one-for-one sources ... but rather resources Shakespeare could employ as stimuli to evoke audience response in his creation of a great work of art."8 I would like to position myself carefully within the field of studies in 
intertextuality, proceeding expansively, not restrictively. With Donna Hamilton, I "take exception with those studies that seek to trace any single idiom to a single text .... Most of the language at issue comprises a continuous discourse that is available in many texts written over many years."9 Kenneth Muir explains how I believe this "continuous discourse" works in Shakespeare's borrowings: ${ }^{10}$

[W]e may suppose that, like Coleridge, he created much of his poetry from forgotten reading. ... It must therefore be borne in mind that apparently close parallels may be deceptive, and that even when Shakespeare is known to have read the work in question, his actual source may be different.... [A] single line in one of his plays may combine echoes of more than one source. ... Shakespeare thus combined a variety of different sources in the texture of his verse, and the process, in most cases, was apparently unconscious. Just as ... "The Ancient Mariner" and "Kubla Khan" were a complex tissue of words and phrases borrowed from Coleridge's multifarious, and probably forgotten, reading, so it would be possible, if we had a complete knowledge of Shakespeare's reading, to show that words, phrases, and images coalesced in his poetry. ${ }^{11}$

In the case of Hamlet, then, there may or may not have been a "programme of reading he carried out for the specific purpose of writing."12 But to attempt to descend into "that dark undercellarage"13 of the writing process which precedes any final product, I have tried to examine more thoroughly what cultural baggage may have been kept in storage in the cellars of William Shakespeare.

It is beyond question that Shakespeare used the two treatises I propose as intertexts when he wrote several other plays. ${ }^{14}$ They have simply not been emphasized as important in relation to Hamlet. ${ }^{15}$ Here I should make clear that both expansionist ${ }^{16}$ and reductionist ${ }^{17}$ critics have amassed improbable or incomplete lists of intertexts for Hamlet. The expansionist critics, who claim to offer a plurality of "sources," do not include the two which I believe they should not leave out, but at least they leave open the pathway for their future inclusion. My greater objection is to the work of the reductionists, who prefer a select few "sources" over a variety of others, thereby blocking further efforts to establish intertextual, interdependent relationships. They obstruct further understanding by privileging exotic or obscure sources over what I would argue to be obvious choices.

The critics who do mention Daemonologie or the Discouerie usually do so in a cursory manner. ${ }^{18} \mathrm{~A}$ few critics do quote a sentence or two from one or the other of these treatise writers. ${ }^{19}$ Eleanor Prosser is the foremost, and most controversial, "Hamlet Ghost" critic. ${ }^{20}$ Along with Prosser, J. Dover Wilson comes the closest among Anglophone critics to uncovering these 
particular intertexts of Hamlet. ${ }^{21}$ Benno Tschischwitz, a German scholar, seems to have been the critic who saw fit to place the most emphasis on Daemonologie as an intertext of Hamlet. 22

Cumbersome as these tomes are, and lacking in resonance for the modern reader (uninterested in finely-tuned arguments on supernatural topics not belonging to today's milieu), the Daemonologie and Discoverie were best-sellers in their own time and deserve to be read in their own right. The fact that they are not is symptomatic of what Keith Whinnom has called a

discrepancy between what the readers, and writers, of former generations preferred to read, and what we, as professional critics and historians, choose to study and make our students study. ... . [I]f . . . we consistently ignore or pay scant attention to writers and works which at one time everyone read with enthusiasm, I cannot help feeling that ... we must be failing in our task. ${ }^{23}$

He continues emphatically, "so long as histories of literature remain uncontrolled by more objective criteria than they are, they will tend to reflect our own contemporary ethos rather than that of the age whose literary history they purport to narrate." 24 I could not agree more.

Critics searching for "sources" of Hamlet have sometimes remained so narrowly focused on a specific hermeneutical tangle, such as the nature of the Ghost, that they have failed to look for intertexts which might be relevant on a far less subtle level, such as shared discourse or terminology and certain plot details. ${ }^{25}$ In other words, perhaps they have read too selectively. Similarly, they may have relegated the more specific treatises on exorcism to Lear specialists, the handbooks on witchcraft to Macbeth experts, and so on. The territoriality of recent scholarship has caused younger scholars to avoid exorcistic lore as the space already staked out by (for example) Stephen Greenblatt, John Murphy, and Frank Brownlow. ${ }^{26}$ Interestingly enough, most of the passages I identify here as intertexts of Hamlet come from sections of the two treatises which deal with exorcism. Because critics have not seen this play in light of this material as they have done with King Lear, perhaps they have skipped over these sections of the treatises and focused instead on discussions of pneumatology. Instead of looking for common threads of intertextuality running through the Shakespeare corpus, they have preferred to make claims for original scholarly contributions by reading certain plays not in light of established intertexts of other plays but instead in relation to more obscure documents of which no one has ever heard. The results are arguments that may be more innovative but less probable. It is precisely Shakespeare's use of, for example, Daemonologie in Macbeth and 
his appropriations from Reginald Scot in The Tempest that make the idea of these treatises as intertexts for Hamlet so plausible. If they affected his consciousness on one or more occasions, why not again? His preoccupations with recurring themes have led many scholars to conclude that he even returned to his own plays as further intertexts. ${ }^{27}$

Now it is time to look at these two specific intertexts, The Discouerie of Witchcraft (1584) by Reginald Scot and Daemonologie (1597) by King James I, and their relation to Hamlet. One interesting verbal echo which these two treatises share with each other and with Hamlet is very clearly a fragment of an ongoing cultural dialogue. The phrase is not unique to these texts, but in the case of one of them, it is repeated with emphatic frequency. The fragment is re-inscribed in the following lines spoken by Hamlet: 28

... The spirit that I have seen

May be a [dev'l], and the [dev'l] hath power

T'assume a pleasing shape, yea, and perhaps,

Out of my weakness and my melancholy,

As he is very potent with such spirits,

Abuses me to damn me. . (2.2.598-603). ${ }^{29}$

Some intertexts for these lines are the following passages from these treatises, the first from King James's Daemonologie, the second from Reginald Scot's Discouerie of Witchcraft, and the last two once more from King James's Daemonologie.

[H]e [the devil] affrayeth and troubleth the bodies of men: For . . the abusing of the soule. $^{30}$

But surelie it is almost incredible, how imagination shall abuse such as are subject unto melancholie; so as they shall beleeve they see, heare, and doo that, which never was nor shall be. ${ }^{31}$

Hath the Devill then power to appeare to any other, except to such as are his sworne disciples: especially since al Oracles, and such like kinds of illusiones were taken awaie and abolished by the cumming of Christ? [Answer:] ... that these abusing spirites, ceases not sensine at sometimes to appeare, dailie experience teaches us ... 32

[There are] spirites, who for abusing the more of mankinde, takes on these sundrie shapes, and uses diverse formes of out-ward actiones. ${ }^{33}$ 
Along with this general level of intertextuality or shared discourse, these treatises and this play show other, more specific points of contact. The whole scene where the Ghost first appears is also illuminated by these two treatises. The internal stage directions tell us that the Ghost walks away no surprise, considering that, according to Reginald Scot, "[n]o man is lord ouer a spirit, to reteine a spirit at his pleasure." 34 It is also no surprise that the Ghost appears wearing armor, a detail which corresponds to Biblical expressions of diabolical strength invoked by Renaissance treatise writers: "the diuell is called ... a strong armed man ... the most subtill, strong and mightie enimie." 35 The speculation by Horatio and Marcellus about the Ghost's warlike appearance is given an added facet of meaning by this detail from King James:

[The devil will appear] in the formes he will oblish him/selfe, to enter in a dead bodie, and there out of to give such answers, of the event of battels, of maters concerning the estate of commonwelths, and such like other great questions. ${ }^{36}$

The two men keeping watch in Hamlet discuss "the event of battles" (Denmark's conflict with Fortinbras of Norway) and "matters concerning the estate of commonwealths": they comment, "This [the Ghost's appearance] bodes some strange eruption to our state" (1.1.69).

Still further demonological details from these treatises illuminate certain aspects of the play. The Ghost appears at night ("soules appeare oftenest by night" 37 ) because the demonologically-informed audience would expect "his nightwalkings, his visible appearings." 38 The exorcistic template for this sort of experience also mandates that Hamlet warn his friends not to hinder him. The following passage, which describes an exorcism, sounds like the guards, the Ghost, and Hamlet, with their various interactions: ${ }^{39}$

[i]f the spirit make anie sound of voice, or knocking, at naming of anie one, he is the cousener (the conjuror I would saie) that must have the charge of this conjuration or examination. And these forsooth must be the interrogatories, to wit: Whose soule ar thou? Wherefore comest thou? What wouldest thou have? [. . .] This must be done in the night .... There is no feare (they saie) that such a spirit will hurt the conjuror. . 40

Horatio is the designated "exorcist" in this scene because scholars know Latin, the language of exorcism; Marcellus says "Thou art a scholar, speak to it, Horatio" (1.1.42). He does in fact ask the Ghost these exact questions: "What art thou that usurp'st this time of night .. .? By heaven I charge thee speak!" (1.1.46-49). 
It is also not surprising that the Ghost returns to speak with Hamlet, for the spirit described here always "settes an other tryist, where they may meete againe." "4l One further detail from the Ghost's return is also present in both of the treatises as well as the play: the fear that the Ghost might lead Hamlet to fall from a cliff. This piece of religious lore was derived from a common source, the Biblical account in Luke 4:5. King James stated explicitly that devils were fond of leading their victims to high places from which they might fall. Reginald Scot wrote in a slightly different context: "whatsoever is newlie exorcised must be rebaptised: for (saie they) call them by their names, and presentlie they wake, or fall if they clime. . ." 42 The corresponding lines of the play are Horatio's: "What if it tempt you toward the flood, my lord/ Or to the dreadfull summit of the cliff" (1.4.69-70).

The "Ghost critics" have illuminated for us the fact that for these two treatise writers, one of the shapes that devils could take on was the form of a dead friend. King James I believed that the devil, when appearing to men, frequently assumed the form of a person newly dead to possess the soul of one still alive. ${ }^{43}$ Prosser has argued that this happened in the case of Old Hamlet (though basing her argument, I might add, on texts distinct from this one). From Reginald Scot's perspective, a person was especially prone to see apparitions of devils in the shapes of dead friends when he was already melancholy, or susceptible to demonic influence: "[m]anie thorough melancholie doo imagine, that they see or heare visions, spirits, ghosts, strange noises . .."44 King James agrees:

[a]nd finding them in an utter despair ... he [the devil] prepares the way by feeding them craftely in their humour, and filling them further and further with dispaire, while he finde the time proper to discover himself unto them. At which time ... in likeness of a man, inquires of them, what troubles them: and promiseth them, a suddaine and certaine waie of remedie. ${ }^{45}$

A similar passage from a different treatise illuminates for us the scene in which the Ghost appears to Hamlet, but Gertrude cannot see him:

[T] hey either appeare imaginatiuely by mouing humours and blood (and thereby forme certain apparitions) or they appeare in assumpted bodies, appropriat to their intents ... and if according to imagination, they appeare to none but to those to whom the vision appertaineth: but if in an assumed body, it is by their power, and in that sort are subiect to many mens sights. ${ }^{46}$

It certainly fits the paradigm presented by both of these treatises that the younger, suicidal Hamlet should see such an apparition or imagine that he does, for "they are oftenest seene by them that are readie to die." 47 
The Ghost's ultimate purpose also fits neatly with certain details of these two treatises. The two treatise writers explain the desire for revenge in a way that sounds like the Ghost luring Hamlet: "[s]uch as ... burnes in a despaire desire of revenge, hee [the devil] allures them by promises, to get their turne satisfied to their hartes contentment." 48 In afflicting madmen, this type of spirit specializes in "teaching them waies howe to get themselves revenged." 49 King James explains this concept in ways that cast light upon Hamlet:

[T] hese kindes of spirites, when they appeare in the shaddow of a person newlie dead ... to his friendes ... When they appeare upon that occasion, they are called Wraithes in our language. Amongst the Gentiles the Devill used that much, to make them beleeve that it was some good spirite that appeared to them ... to discover unto them, the will of the defunct, or what was the way of his slauchter, as is written in the booke of the histories Prodigious. And this way hee easelie deceived the Gentiles, because they knew not God: And to the same effect is it, that he now appeares in that maner to some ignorant Christians. ${ }^{50}$

As the reader or audience of Hamlet will remember, the Ghost "discovers unto" Hamlet both "the will of the defunct" and the way of his slaughter." He informs him: "The serpent that did sting thy father's life/ Now wears his crown" (1.5.38-39). The Ghost then describes the murder in gruesome detail, how the "leprous distillment" took its effect.

$$
* \quad * \quad *
$$

And what effect does the Ghost's message have upon Hamlet? Critics agree that the Ghost's message is one of the provocative factors in Hamlet's downward spiral into madness. The assertion of his authority over Hamlet - and his ability to manipulate the vulnerable young man — take the form of a boast of the demonic powers to which he has access:

I could a tale unfold whose lightest word

Would harrow up thy soul, freeze thy young blood,

Make thy two eyes like stars start from their spheres,

Thy knotted and combined locks to part,

And each particular hair to stand on end,

Like quills upon the fearful porpentine.

As Hamlet's later madness (sometimes manifested using a "mask" of the symptoms of possession) demonstrates, the Ghost is capable of engendering all these responses and more. Gertrude later describes Hamlet's appearance using the language of the exorcists to describe demoniacs: 
Forth at your eyes your spirits wildly peep, And as the sleeping soldiers in th' alarm, Your bedded hair, like life in excrements, Start up and stand on end. ... (3.4.119-22)

The half-dressed Hamlet also appears to Ophelia in her closet with his garters crossed (a typical feature of demoniacs) "[a]s if he had been loosed out of hell" (2.1.80). And he wonders aloud, asking who is responsible for the symptoms (classic signs of demonic possession) that he feels:

Who calls me villain, breaks my pate across,

Plucks off my beard and blows it in my face,

Tweaks me by the nose, gives me the lie i' th' throat

As deep as the lungs? Who does me this?

It is a commonplace of Hamlet criticism that these symptoms should be attributed to melancholy. But in order to grasp more fully the multi-faceted nature of Hamlet's madness, let us examine period concepts of melancholy as they are explained in these two treatises. King James, in his Daemonologie, describes this illness: "[f]or as the humor of Melancholie in the selfe is blacke, heaule and terrene, so are the symptomes thereof, in any persones that are subject thereunto, leannes, palenes, desires of solitude: and oft they come to the highest degree thereof, mere folie and Manie." 51 John Draper quotes this passage from King James and then comments, "Hamlet aptly remarks that melancholy persons are especially predisposed to demonic influences." 52 What most other critics seem to ignore, however, is the fact that, for many Elizabethans or Jacobeans, melancholy was actually caused by demons. Reginald Scot explains that the devil "provoketh the merrie to loosenesse, and the sad to despaire." 53 King James describes how Satan and his devils produce the symptoms we recognize: "[t]hey can make folkes to becom phrenticque or Maniacque, which likewise is very possible to their master to do, sence they are but naturall sicknesses." 54 We recognize further symptoms of Hamlet: "[ $t$ ]his [melancholy] maketh sufferance of torments, and (as some saie) foresight of things to come ... it maketh men subject to leanenesse, and to the quartane ague. They that are vexed therewith, are destroiers of themselves, stout to suffer injurie, fearefull to offer violence." 55 This would seem to be the perfect picture of the sickly, suicidal Hamlet. King James proposed, in writing his treatise, to leave "the reasones refuted of all such as would call it but an imagination and Melancholique [i.e., not diabolical] humor." $56 \mathrm{He}$ defines the very phenomenon of demonic 
possession, conversely, as what "is thought likewise to be but verie melancholicque imaginations of simple raving creatures." 57

Therefore we see that even if Hamlet's ailment is "only" melancholy, our understanding of his illness calls for further nuancing if we would glimpse Hamlet's many faces of madness. Shakespeare probably knew Timothy Bright's Treatise of Melancholie (1586), and it probably contributed to his portrayal of Hamlet, yet few scholars have investigated what other intertexts might also lie beneath the melancholy topos of the play. Neglecting to move beyond modern assumptions, they turn to medical instead of demonological treatises.

Although the focus of this essay is on the Ghost and its provocation of Hamlet's madness, it is worth noting that some scholars have also seen Ophelia's melancholy madness as diabolical and thus, more verisimilar to the play's audience: "If Ophelia ... was regarded as being possessed, then her auditors would discern more than one personality emergent in her various ravings, and would be justified in assuming she was possessed of several demons." 58 It should also be remembered in this context that suicide was often explained as the ultimate consequence of diabolical possession. The case of Ophelia reminds us that madness and suicide permeate this play, ${ }^{59}$ as does the demonic linguistic register.

What are the thematic implications of the appearance of this demonic linguistic register? It has already been stated that intertextuality or discourse fragmentation leads to madness. But as we have hinted earlier, we might see Hamlet's "mad" fragmented discourse as part of a larger pattern in his character, ${ }^{60}$ a pattern of what should be called performativity as distinguished from self-fashioning. Self-fashioning has been defined by New Historicists and Cultural Materialists as "a sense of personal order, a characteristic mode of address to the world, a structure of bounded desires elements of deliberate shaping in the formation and expression of identity." 61 It is the logical modernist conception of the heightened sense of individualism recognized since Burckhardt as a hallmark of the Renaissance. Performativity, more a concern for postmodern critics, presents quite a distinct phenomenon. For one thing, this term is often reserved for discussions of dramatic genres of literature, as metatheater seems impossible or irrelevant in prose or lyric poetry. Performativity is also easily distinguishable from self-fashioning by virtue of its relative lack of concern for coherence. Self-fashioning has as its goal the production of a unified 
identity/image; performativity encompasses many identities or iterations of images being explored and then discarded.

\section{Robert Miola describes Hamlet's fragmented performativity:}

Part parody, part earnest attempt at self-creation, these switches into and out of tragic idiom limn Hamlet's great struggle to create his part in the evolving and confusing drama at Elsinore. Such rapid switching, marked by sharp contrasts in tone and mood ... [t]hese moments resonate with the many references to theatre and playing, beginning with Hamlet's opening remark about the forms, moods, and shapes of his grief as "actions that a man might play" (I.ii.84) ... . Hamlet insistently calls attention to itself as play $\ldots$ to encourage and discourage belief. ${ }^{62}$

Through his agile performativity, Hamlet is "fabricator of multiple fictions and multiple truths":

Shakespeare elsewhere shows a clear preference for errors. At its most profound levels Hamlet is an errors play. As Levin remarks, it abounds in "errors or supposes, misconceptions contrived and coincidental. Even the Ghost raises the question of a possible disguise... . The tutelary goddess again ... is Agnoia, "misapprehension," though she appears here in subtler, more disturbing form." 63

The text of the play itself affirms this interpretation with Horatio's assessment of "purposes mistook" (5.2.384). Another passage that is reflective of the performativity element is Hamlet's "conversation with Ophelia about beauty, honesty and discourse (III.i.103-15) [which] links his emotional concerns and his awareness that speech is common to a multitude of meanings rather than honest to one."64

Many critics have made use of the performativity theme to elevate Hamlet to the status of ultimate Protean, but few have interpreted the Ghost in light of this same performativity theme - an essential element of the play as a whole. I would postulate that these treatises illuminate not only Hamlet's shifting perspective on the Ghost but also the iterations the Ghost itself performs. Surely "the growing and often anxious Renaissance awareness of historical multiplicity and of a proliferation of human meaning" 65 could extend to the Ghost as well.

In each of their many guises, Hamlet and the Ghost both invite misunderstanding. ${ }^{66}$ If Hamlet plays the part of a demoniac at certain moments, the audience will associate him with madness. If the Ghost plays the part of a demon or a damned soul, the audience will catch this nuance. These moments of anagnorisis recall Aristotle's "recognition by dramatic representation" as explained in the Poetics. By attempting to reduce the Ghost to Catholic, Protestant, or pagan, the "Ghost critics" were missing the point. I 
believe the Ghost appears Catholic one moment, Protestant the next, and pagan the third precisely because he, like Hamlet, tries on different identities in the course of the play. If the whole of Hamlet is a play in which identity is problematized, then why should not the Ghost play as many rôles, try on as many masks?

An awareness of this performativity opens up critical horizons and prevents reductive readings of the play. If we wish to discuss any one particular reading of the play - for instance, demonological motifs in relation to Hamlet - we may do so with the proviso that this is only one model for his madness. No one model is supposed to fit all the way; otherwise the play would be reduced to a flatness, a lack of texture, a univocality which is unthinkable for Shakespeare. Anon-reductionist view of the intertextuality of these two treatises and this play only adds more texture to a text already rich in meaning. It is another tribute to Shakespeare's art that we are taken in by the incessant trying on of different identities by both Hamlet and the Ghost in this play - so much so that critics have, for centuries, partaken of it and attempted to invent pat labels for these polyvalent characters.

\section{Princeton University}

\section{Notes}

1. Peter Hughes, "'Playing with Grief': Hamlet and the Rituals of Mourning," Comparative Criticism, 9 (1987), p. 118. Hughes writes specifically of the Catholic language in Hamlet as "a series of negations or denials of ritual acts" (p. 129).

2. Elizabeth C. Fine and Jean Haskell Speer, Performance, Culture, and Identity (Westport, CT: Praeger, 1992), p. 17.

3. I must note that both of the intertexts I use in the discussion that follows were published before the play Hamlet was written (probably 1600-1601) and thus were accessible to Shakespeare - whether or not he chose to use them for this play, as most scholars believe he did for other plays of his.

4. "Texts, Printing, Readings," in The New Cultural History, ed. Lynn Hunt (Berkeley: University of California Press, 1989), pp. 171, 173.

5. Alison Findlay, "Hamlet: A Document in Madness," in New Essays on Hamlet, ed. Mark Thornton Burnett and John Manning (New York: AMS, 1994), p. 189.

6. Madness and Civilization: A History of Insanity in the Age of Reason, tr. Richard Howard (London: Tavistock, 1967), p. 19; cited in Findlay, p. 191.

7. Sanford Sternlicht, "Hamlet - The Actor as Prince," Hamlet Studies, 4, 1 (1982), p. 19.

8. Roland Mushat Frye, The Renaissance Hamlet: Issues and Responses in 1600 (Princeton: Princeton University Press, 1984), p. 6. 
9. Donna B. Hamilton, Shakespeare and the Politics of Protestant England (Lexington: University Press of Kentucky, 1992), p. 203.

10. For a scholar who precedes Muir on the generation of intertextuality, see A. P. Stabler, "Melancholy, Ambition, and Revenge in Belleforest's Hamlet," PMLA, 81,1 (1966): 207-13. Frank Brownlow also offers a rather passionate defense of intertextual studies: "[A] commentator who wants to gloss his text accurately needs an explorer's willingness to travel in unmapped country as well as an archacologist's patience in moving, tentatively and sceptically, from clue to clue. If critics are to know what they are talking about, however, such work is necessary; and besides extending the mental boundaries of the contemporary reader, the ideas recovered often throw light upon the whole meaning and atmosphere of a work. ... Risky as it is to trace the workings of another mind, ... [o]ne age's clichés are another's preoccupations" ("Samuel Harsnett and the Meaning of Othello's 'Suffocating Streams," Philological Quarterly, 58 [1979], pp. 112-13).

11. Kenneth Muir, The Sources of Shakespeare's Plays (New Haven: Yale University Press, 1978), pp. 7, 10-11.

12. Ibid., p. 217.

13. Winfried Schleiner, "The Feste-Malvolio Scene in Twelfth Night Against the Background of Renaissance Ideas About Madness and Possession," Deutsche Shakespeare Gesellschaft West: Jahrbuch (1990), p. 48.

14. One frequently encounters statements such as, "Discouerie of Witchcraft . . . is recognised by all as one of Shakespeare's source-books" (J. Dover Wilson, What Happens in Hamlet [New York: Macmillan, 1936], p. 63).

15. Kenneth Muir acknowledges Scot's Discouerie as a source for the fairy material in $A$ Midsummer Night's Dream, the Weïrd Sisters in Macbeth, and Shakespeare's "treatment of the supernatural" in Hamlet (Muir, p. 167; he gives no further details). See also pp. 67 and 216. He also cites Daemonologie as a source for Macbeth. John Erskine Hankins cites Daemonologie as a source for the contest of epithets in I Henry IV (Backgrounds of Shakespeare's Thought [Hamden, CT: Archon, 1978], pp. 122-23). Jacqueline Latham has attempted to demonstrate a connection between The Tempest and Daemonologie ("The Tempest and King James's Daemonologie," Shakespeare Survey, 28 [1975]: 117-23).

16. The expansionists are those who purport to offer multiple background materials to illuminate this play for readers and spectators. Many of these critics, preferring to discuss sources like Belleforest, Saxo Grammaticus, or Fratricide Punished, allude briefly to a phrase like "Elizabethan demonology" and leave it at that. See F. W. Moorman, "The Pre-Shakespearean Ghost," Modern Language Review, 1, 3 (1906): 85-95. There are also one-sentence treatments such as "[ $t]$ he possibly demonic character of Hamlet's charge is specifically on his mind" (Gordon Braden, Renaissance Tragedy and the Senecan Tradition: Anger's Privilege [New Haven: Yale University Press, 1985], p. 218). Geoffrey Bullough, in his gargantuan series Narrative and Dramatic Sources of Shakespeare, never mentions either Discouerie or Daemonology as any sort of "source" for the play, even though Reginald Scot wrote an entire chapter titled "Of visions, noises, apparitions, and imagined sounds, and of other illusions, of wandering soules. ..." Pinciss and Lockyer mention Hamlet in relation to Reginald Scot and categorize three possible adjectives for the Ghost: Senecan, demonic, and conscience-like. They conclude a short paragraph with, "[n]o doubt, Shakespeare is exploiting the ambiguity about the possible nature of the ghost for dramatic effect" (Gerald 
M. Pinciss and Roger Lockyer, Shakespeare's World: Background Readings in the English Renaissance [New York: Continuum, 1989], p. 74).

17. The reductionists are those who limit their discussion of Shakespeare's "sources" to one or very few. For example, Battenhouse juxtaposes Lewis Lavater, a logical choice, with St. Augustine, an illogical one. He at least mentions Scot, but only to guess that Shakespeare intended that the Ghost pertain to a particular class of devils, the subterranei (Roy W. Battenhouse, "The Ghost in Hamlet: A Catholic 'Linchpin'?," Studies in Philology, 48, 2 (1951): 161-92). The primary source he uses is Lavater's Of Ghostes and Spirites Walking by Nyght (trans. R. H[arrison] [London: H. Benneymann for R. Watkyns, 1572]). Another critic emphasizing Lavater is F. W. Moorman in "Shakespeare's Ghosts," Modern Language Review, 1, 2 (1906): 192-201. Moorman does, however, at least mention the title of both of these treatises: "[ $[$ ] hat the discussion [about ghosts] is a protracted one, is shown by King James's absorption in it in his Demonologie, and by the fact that [Reginald Scot also treats it in Discouerie]" (pp. 197-98). Lawrence Babb ("Hamlet, Melancholy, and the Devil," in The Elizabethan Malady: A Study of Melancholia in English Literature from 1580 to 1642 [East Lansing: Michigan State College Press, 1951], pp. 120-22) cites Wier and Agrippa, both Continental demonologists, and explains in a note that Reginald Scot could have been a purveyor of Wier's ideas in England.

18. Thomas Alfred Spalding noted that "al though the devil could not, of his own inherent power, create a body, he might get hold of a dead carcase and temporarily restore animation, and so serve his twin. This belief was held, amongst others, by the erudite King James" (Elizabethan Demonology: In Illustration of the Belief in the Existence of Devils, and the Powers Possessed by Them, As It Was Generally Held During the Period of the Reformation, and the Times Immediately Succeeding; With Special Reference to Shakspere and His Works [London: Chatto \& Windus, Piccadilly, 1880], p. 44). He refers to Daemonologie, p. 56. Spalding cites three page numbers from King James (I, v, 92; II, ii, 627; and III, ii, 87), without passages from them, and explains, "[t]he idea that the devil assumed the form of a dead friend in order to procure the 'tinsell' of both body and soul of his victim is here before the minds of the speakers of these passages" (Spalding, p. 58). Roland Frye notes briefly that King James was interested in demonology, and that demonological material is in some way relevant to Hamlet. He later cites J. Dover Wilson and Robert H. West: "King James I also pictured the Devil as leading his victim on to guilt through desire of revenge, as appearing in the likeness of one dear to the victim in order to secure his attention, as taking advantage of his victim's despair to entice him to his own destruction" (Frye, p. 23; see also West, "King Hamlet's Ambiguous Ghost," PMLA, 70, 4 [1955]: 1107-17). (Many critics have suspected that the alleged responsibility of Hamlet to avenge a murdered parent may have, in some way, achieved greater topicality in Shakespeare's day because of James I's turmoil over the murder of his own father, to which his mother was said to have been an accomplice.) Sister Miriam Joseph echoes J. Dover Wilson's tidy theory that the four characters who see the Ghost represent three distinct theological perspectives on ghosts; among them, Horatio is the voice of Reginald Scot, while Hamlet speaks for both Lavater and King James ("Discerning the Ghost in Hamlet," PMLA, 76,2 [1961]: 493-502). See Paul N. Siegel's response to her article in PMLA, 78, 1 (1963): 148-49.

19. Arthur McGee refers to a sentence (which I recognize as being from Daemonologie) that he may have drawn from the citation of another critic, as he does not give the source himself: "James I wrote, referring to the Devil: 'so ambitious is hee and greedy of honour.' Thus a 
Fortinbras possessed of such 'ambition' was also possessed of the Devil" (The Elizabethan Hamlet [New Haven: Yale University Press, 1987], p. 92).

20. Eleanor Prosser, Hamlet and Revenge (Stanford: Stanford University Press, 1967). Her approach takes a somewhat exclusionary view of each leading religious denomination. She draws out the minutely detailed intricacies of each denomination's hypothetical approach to the Ghost. For the Catholic position, she marshals evidence from two French sources: Le Loyer's III Livres des spectres and Taillepied's Psichologie ou traité de l'apparition des esprits. For the Protestant view, she relies primarily on Lavater, although in a note she lists other authors whom she sees as apologists for the dogmas of various denominations. Prosser does include King James, and the title of his work, in this list, along with Reginald Scot. Her ultimate conclusion is that preceding critics had mistakenly assumed that different denominations would have held opposing views on the Ghost. She claims that from the perspective of any denomination, the Ghost would have been recognized as a demon.

21. He draws attention to one of the appropriate passages in Reginald Scot and explains that the "threefold oath finds ... a parallel in Scot who speaks of "promises and oths interchangeable made betweene the coniuror and the spirit,' oaths which were sworn three times and for the violation of which eternal penalties were exacted. . . Marcellus to his dying day will believe that he has sworn an oath thrice in the hearing of a powerful fiend, and will hold his tongue" (J. Dover Wilson, What Happens in Hamlet, p. 82). He also mentions that King James believed ghosts were devils, and that these beings might lead men to high places from which they would fall. He connects this detail to Hamlet and the Ghost's leading him away from his friends.

22. He begins with, "[w]as zunächst die Enwähnung der Melancholie betrifft, so belehrt uns ein ursprünglich in englischer Sprache verfasstes Werk König Jacob's, die 'Daemonologie'” (Shakspere's Hamlet in seinem Verhältniss zur Gesammtbildung, namentlich zur Theologie und Philosophie der Elisabeth-Zeit [Halle: Waisenhaus, 1867], p. 10). It is symptomatic of the Anglocentric nature of Anglophone critics that only J. Dover Wilson (p. 78) cites Tschischwitz, even though his topic was so pertinent to the work of all the "Ghost critics."

23. Keith Whinnom, "The Problem of the 'Best-Seller' in Spanish Golden Age Literature," Bulletin of Hispanic Studies, 57, 3 (1980), p. 189.

24. Ibid., p. 190.

25. Renaissance authors did not hesitate to engage in "borrowing" from sources to an extent that we might even consider plagiarism. See William H. Sherman, John Dee: The Politics of Reading and Writing in the English Renaissance (Amherst: University of Massachusetts Press, 1995), pp. 122-23. Sherman quotes Terence Cave, The Cormucopian Text: Problems of Writing in the French Renaissance (Oxford: Oxford University Press, 1979), p. 76.

26. Stephen Greenblatt, "Shakespeare and the Exorcists," in Shakespearean Negotiations: The Circulation of Social Energy in Renaissance England (Berkeley: University of California Press, 1988), pp. 94-128; John L. Murphy, Darkness and Devils: Exorcism and King Lear (Athens, OH: Ohio University Press, 1984); and F. W. Brownlow, Shakespeare, Harsnett, and the Devils of Denham (London \& Toronto: Associated University Presses, 1993).

27. This point even emerged during the last decade in a venue of modern popular culture. The front-page feature "A Sleuth Gets His Suspect: Shakespeare," by William H. Honan, appearing in the January 14, 1996 New York Times, outlined Professor Donald Foster's mass 
of evidence, including echoes of specific words from plays Shakespeare was writing at the time, that the bard wrote a newly-rediscovered funeral elegy for William Peter.

28. All the emphases are mine.

29. William Shakespeare, Hamlet, in The Riverside Shakespeare, ed. G. Blakemore Evans (Boston: Houghton Mifflin, 1974). All references in the text are to this edition. See notes on p. 1190 concerning variations on the word [dev'l] in the earliest editions: the Third and Fourth Quartos read "a diuell ... a diuelll," while the First Folio reads "the Diuell . . Diuel"; the First Quarto, similarly, reads "the Diuell."

30. James VI. of Scotland and I. of England, Daemonologie (Edinburgh: Robert Walde-graue, 1597), p. 56.

31. Reginald Scot, The Discouerie of Witchcraft. With a Discourse upon divels and spirits, and first of philosophers opinions, also the manner of their reasoning hereupon; and the same confuted (London: William Brome, 1584), p. 68.

32. King James I, Daemonologie, p. 53.

33. Ibid., p. 57.

34. Scot, p. 516.

35. Ibid., p. 539. The Biblical allusion here may be to Luke 11:21-22.

36. King James I, Daemonologie, p. 20.

37. Scot, p. 535.

38. Ibid., p. 540.

39. A conversely similar scene occurs in Macbeth when Banquo's ghost appears: "Macbeth now suspects that it is a question of a demon imitating Banquo's appearance - just as Hamlet thought for a time that the Ghost might be a devil rather than his father's spirit... . Basically, what Macbeth seems to be trying to do is 'lay' - exorcize - the apparition... . Perhaps the apparent success of this exorcism suggests or confirms to Macbeth - as it may have done to the audience - the nature of the being haunting him" (Martin Puhvel, "The Perplexing Ghost of Banquo: Ambiguity and its Roots," Neuphilologische Mitteilungen, 94 [1993], pp. 290-91).

40. Scot, p. 434.

41. King James I, Daemonologie, p. 33.

42. Scot, p. 442.

43. King James I, Daemonologie, p. 60.

44. Scot, p. 461.

45. King James I, Daemonologie, pp. 32-33.

46. Thomas Lodge, The Diuel Coniured (London: Adam Islip for William Mats, 1596), pp. 16-17. Roland Frye also recognizes the correspondence of this passage to two of the Ghost's appearances, the first and the one in which Gertrude cannot see it (p. 16). This intertext demonstrates that most of these phrases and images were part of an ongoing cultural dialogue among various demonologists and literary artists.

47. Scot, p. 535. 
48. King James I, Daemonologie, p. 32.

49. Ibid., p. 34.

50. Ibid., pp. 60-61.

51. Ibid., p. 30.

52. John W. Draper, The Humors \& Shakespeare's Characters (Durham: Duke University Press, 1945), pp. 64-65. Lawrence Babb recognizes the connection of Scot to melancholy (especially in those women accused of witchcraft) but not to Hamlet. See The Elizabethan Malady, p. 55. See also Aubrey C. Kail, The Medical Mind of Shakespeare (Balgowlah, NSW: Williams \& Wilkins, 1986); and F. David Hoeniger, Medicine and Shakespeare in the English Renaissance (Newark: University of Delaware Press, 1992). A similar study which does include mention of Daemonologie as pertinent to the general milieu of Shakespeare is Irving Edgar, Shakespeare, Medicine and Psychiatry (New York: Philosophical Library, 1970). For a study of melancholy / madness among Hamlet's historical counterparts in Germany during this time period, see H. C. Erik Midelfort, Mad Princes of Renaissance Germany (Charlottesville: University Press of Virginia, 1994). See especially Part II, "The Age of the Melancholy Prince."

53. Scot, p. 508.

54. King James I, Daemonologie, p. 47.

55. Scot, p. 58.

56. King James I, Daemonologie, p. 27.

57. Ibid., p. 28.

58. Roger Baker, Binding the Devil: Exorcism Past and Present (New York: Hawthorn, 1975), p. 47.

59. See Carol Thomas Neely, "'Documents in Madness': Reading Madness and Gender in Shakespeare's Tragedies and Early Modern Culture," Shakespeare Quarterly, 42, 3 (1991): 315-38.

60. Avi Erlich sees the discrepancies in Hamlet's discourse - as manifested in his shifting attitude toward the Ghost - as related to a broader psychological ambivalence toward his father. See Avi Erlich, Hamlet's Absent Father (Princeton: Princeton University Press, 1977). See also Richard Flatter, Hamlet's Father (New Haven: Yale University Press, 1949). This is obviously the psychoanalytical approach to the problem of Hamlet's fragmented discourse. The linguistic approach would probably describe his ambivalence as codeswitching.

61. Stephen Greenblatt, Renaissance Self-Fashioning: From More to Shakespeare (Chicago: University of Chicago Press, 1980), p. 1.

62. Robert S. Miola, Shakespeare and Classical Comedy: The Influence of Plautus and Terence (Oxford: Oxford University Press, 1994), p. 180. Not long before Miola, Marvin Rosenberg had written an entire book on this topic: The Masks of Hamlet (Newark: University of Delaware Press, 1992). See also Karin S. Coddon, “'Suche Strange Desygns': Madness, Subjectivity, and Treason in Hamlet and Elizabethan Culture," Renaissance Drama, 20 n.s. (1989): 51-75. 
63. Miola, pp. 183-84. See also Richard Baumann and Charles L. Briggs, "Poetics and Performance as Critical Perspectives on Language and Social Life," Annual Review of Anthropology, 19 (1990): 59-88. See further Victor Turner, The Anthropology of Performance (New York: PAJ, 1988). Likewise, see Richard Schechner, Between Theater \& Anthropology (Philadelphia: University of Pennsylvania Press, 1985).

64. Findlay, p. 194. This critic has viewed the performativity theme as calling into question language itself - an issue for us since there can be no intertextuality without textuality, and texts are still created by means of language. See also W. F. Hanks, "Text and Textuality," Annual Review of Anthropology, 18 (1989): 95-127.

65. David Quint, Origin and Originality in Renaissance Literature: Versions of the Source (New Haven: Yale University Press, 1983), p. 23.

66. See Harry Levin, The Question of Hamlet (London: Oxford University Press, 1970), p. 120. I would like to thank Larry Danson, Jim Harner, Harry Meserole, and Tony Grafton for reading the manuscript of this article and offering their suggestions. 